\title{
Role of regulatory proteins in HIV-1/HTLV-1 coinfection
}

\author{
Dustin Edwards ${ }^{1}$, Klaus Strebel ${ }^{2}$, Robyn Washington Parks ${ }^{1}$, Cynthia Pise-Masison ${ }^{1}$, Claudio Fenizia', \\ Martina Fiocchi ${ }^{1}$, Genoveffa Franchini ${ }^{{ }^{*}}$ \\ From 16th International Conference on Human Retroviruses: HTLV and Related Viruses \\ Montreal, Canada. 26-30 June 2013
}

In HTLV-1 endemic areas, 5 to $10 \%$ of HIV-1-infected individuals are also coinfected with HTLV-1/2. Several studies support the finding that dual infection of HIV-1 and HTLV-2 may confer delayed AIDS progression. In contrast, HTLV-1 has been concluded to have either no effect or to increase progression to AIDS in HIV-1infected individuals. Although Tax-1 is known to influence HIV-1 replication in vitro, other HTLV-1 proteins likely have a role in retroviral coinfection. Here, we are investigating whether HTLV-1 proteins regulate activation of HIV-1 expression in latently-infected cells. In this study, we used B-cells infected with molecular clones that either express both p12 and p8, p12-only, p8-only, or contain knockouts to orf-I, orf-II, or hbz. The HTLV-1-infected B-cells were cocultured with KK1 $\mathrm{T}$-cells latently-infected with HIV-1. Following coculture, cells and media were assayed for viral expression. Analyses of immunoblot and ELISA data suggest that HTLV-1-infected B-cells that express p8 enhanced activation of latent HIV-1 expression. We are currently examining whether cell-to-cell contact with $\mathrm{p} 8$ expressing cells is required to reactivate the latently-infected KK1 cells. Results from this study could have an impact on treatment of patients coinfected with HIV-1 and HTLV-1.

\section{Authors' details}

${ }^{1}$ Animal Models and Retroviral Vaccines Section, National Cancer Institute, National Institutes of Health, Bethesda, MD, USA. ${ }^{2}$ Laboratory of Molecular Microbiology, National Institute of Allergy and Infectious Diseases, National Institutes of Health, Bethesda, MD, USA.

Published: 7 January 2014

\footnotetext{
* Correspondence: franchig@mail.nih.gov

${ }^{1}$ Animal Models and Retroviral Vaccines Section, National Cancer Institute, National Institutes of Health, Bethesda, MD, USA

Full list of author information is available at the end of the article
}

doi:10.1186/1742-4690-11-S1-P122

Cite this article as: Edwards et al:: Role of regulatory proteins in HIV-1/ HTLV-1 coinfection. Retrovirology 2014 11(Suppl 1):P122.
Submit your next manuscript to BioMed Central and take full advantage of:

- Convenient online submission

- Thorough peer review

- No space constraints or color figure charges

- Immediate publication on acceptance

- Inclusion in PubMed, CAS, Scopus and Google Scholar

- Research which is freely available for redistribution

\section{() Biomed Central}

C Biomed Central

(c) 2014 Edwards et al; licensee BioMed Central Ltd. This is an Open Access article distributed under the terms of the Creative Commons Attribution License (http://creativecommons.org/licenses/by/2.0), which permits unrestricted use, distribution, and reproduction in any medium, provided the original work is properly cited. The Creative Commons Public Domain Dedication waiver (http://creativecommons.org/publicdomain/zero/1.0/) applies to the data made available in this article, unless otherwise stated. 